\title{
Gender Inequality Issues in the Workplace: Case Study of Armenia
}

\section{Gayane Tovmasyan}

$\mathrm{PhD}$, Senior Researcher at "AMBERD” Research Center of the Armenian State University of Economics; Lecturer, Public Administration Academy, the Republic of Armenia

\section{Diana Minasyan}

$\mathrm{PhD}$, Lecturer/Associate Professor, Department of Accounting and Auditing of the Armenian State University of Economics; Chief accountant at CJSC "Factory of reinforced bridge concrete structures", the Republic of Armenia

\begin{abstract}
This paper summarizes the arguments and counterarguments within the scientific discussion on the issue of gender inequality. The main purpose of the research is to find out gender discrimination issues that occur in workplaces in Armenia and suggest some steps for regulating them. Systematization of literary sources and approaches for solving the problem of gender inequality indicates that there are really problems concerning the selection, pay, promotion, evaluation, and other processes in workplaces depending on the gender of an employee. The relevance of the decision of this scientific problem is that female workers face discrimination more than male. Investigation of the topic proves that even in leadership positions men are promoted more than women. Analysis in the paper is carried out in the following logical sequence: the statistical data available are analyzed, and then a survey is done, which reveals some issues of gender inequality in Armenia. Methodological tools of the research methods were analysis and synthesis of the available data, survey, and statistical methods: cross-tabulation with Pearson Chi-square testing, which proves that there are significant relationships between some factors.

The object of the research is the gender inequality issues in Armenia. The paper presents the results of an empirical analysis, which shows that in Armenia women face discrimination in family and workplace, have less opportunities of career promotion, face issues connected with work restrictions, bad attitude, dress code, etc. The research empirically confirms and theoretically proves that the main steps for regulating the issues must be: raising the level of awareness of the people about the subject, making gender equality a component of the educational system, improving public policy, taking more coordinated efforts by non-governmental organizations, etc. The results of the research can be useful for state bodies, labor market, organizations, educational institutions, NGO's, researchers, etc.
\end{abstract}

Keywords: gender, inequality, discrimination, Chi-square testing, survey, index.

JEL Classification: D63, I2, J16.

Cite as: Tovmasyan, G., Minasyan, D. (2019). Gender Inequality Issues in the Workplace: Case Study of Armenia. Business Ethics and Leadership, 3(2), 6-17. http://doi.org/10.21272/bel.3(2).6-17.2019.

(C) The Authors, 2019. This article is published with open access at Sumy State University.

\section{Introduction}

Gender inequality issues really matter in workplaces. Women and men should have equal rights and working conditions, however, it is not always so. Many organizations give less salary to women; women have fewer opportunities to have a career promotion, etc. Gender barriers are in all aspects of life: school, university, workplace, family, etc. This article aims at revealing the gender inequality issues in Armenia, exploring the main reasons and finding some solutions. The article analyzes current data available from the Statistical Committee of the RA, discusses the data of Armenia in Gender Gap report, besides a survey among 200 participants reveals their experiences and faced problems. It states that many people had problems connected with low wages, career promotion, dress code, etc., only because they are female. Also, the statistics shows that there are differences in the labor market between some spheres and also wage rates. In some sectors of the economy women workers are more, and in some sectors male workers exceed. Besides, in all areas, women are paid less than men are. Another problem is that women employers are less than men. The Gender Gap report states issues connected with health and survival index, political empowerment index, the participation of labor force sub-index. 


\section{Literature Review}

Gender issues may occur in HR policies, payment, promotion, etc. Here we will briefly introduce some results of different studies stating gender discrimination practices.

Gender discrimination in decision-making practices relating HR issues arises from gender inequalities in broader organizational structures and practices, such as: HR policies, strategy, structure, leadership, organizational climate, and culture. Besides, the levels of sexism of decision makers' in organizations may affect their probability of making gender-biased decisions about HR practices (Stamarski, Hing, 2015). Institutional discrimination against women may occur in each phase of HR policy from the recruitment and selection of an individual, through his/her role assignments, training, pay, performance evaluations, promotion, and termination (Hough et al., 2001). Studies show that women face personal discrimination during the selection process (e.g., Goldberg, 1968; Rosen and Jerdee, 1974). Agentic women, who behave in an assertive, task-oriented fashion, are less likable and less hirable than comparable agentic male applicants are (Heilman and Okimoto, 2007; Rudman and Phelan, 2008; Rudman et al., 2012). Besides, there is discrimination against pregnant women when they apply for jobs (Hebl et al., 2007; Morgan et al., 2013). Further, mother women are recommended for promotion less than women who are not mothers or men with or without children (Heilman and Okimoto, 2008).

According to research by Dodd-McCue and Wright (1996), once women have children, they cannot be committed to both work and family. However, they demonstrate that it is work experiences, not gender or family roles that predict commitment to work (Dodd-McCue and Wright, 1996). For men, full-time work schedules and family are seen as compatible devotions while the same combination for women are viewed as competing for devotions (Epstein, 2004). Women and especially mothers are potentially held to stricter standards in the workplace compared to men (Correll et al., 2007; Fuegen et al., 2004).

Women receive fewer opportunities at work, compared with men, resulting in their under-representation at higher levels of management and leadership within organizations (Martell et al., 1996; Eagly and Carli, 2007). Managers give women fewer challenging roles and fewer training opportunities, compared with men (King et al., 2012). Men are more likely to be given key leadership assignments (e.g., Maume, 1999; De Pater et al., 2010). Men are also more likely than women to be viewed as effective leaders when occupying roles that are defined in masculine terms, such as in the military (Eagly, Karau, and Makhijani, 1995; Paustian-Underdahl, Walker, and Woehr, 2014) or in corporate leadership positions (Lyness and Heilman, 2006).

Women are slightly more likely than men to be seen as effective leaders in female-dominated industries like education and social work (Eagly et al., 1995; Paustian-Underdahl et al., 2014).

Managers rate women as having less promotion potential than men (Roth et al., 2012). Given the same level of qualifications, managers are less likely to grant promotions to women, compared with men (Lazear and Rosen, 1990). Thus, men have a faster ascent in organizational hierarchies than women (Cox and Harquail, 1991; Stroh et al., 1992; Blau and DeVaro, 2007).

Another research showed that men and women produced gaps in gender payment in their ratings of fairness (Auspurg, Hinz, and Sauer, 2017).

Cohen and Huffman (2007) in their study suggest that the presence of high-status female managers has a much larger impact on gender wage inequality. The promotion of women into management positions may benefit all women, but only if female managers reach relatively high-status positions.

The study of Plickert and Sterling (2017) shows that work schedules significantly vary by gender, parental role, and experience of workplace discrimination. Although all parents experience types of discrimination, there are still major differences in work schedules between mothers and fathers.

Gender standards of leaders restrict women's access to higher positions and the effect of gender increases when there are marital relationships (Yang, Aldrich, 2014).

\section{Discussion}

There are many differences in the types of inequality that face women in different parts of the world - from cultural representation to domestic burdens and child marriage (Whiting K., 2019, an article from www.weforum.org, cited in the references):

1. Women are $47 \%$ more likely to suffer severe injuries in car crashes because safety features are designed for men. 
ISSN (online) - 2520-6311; ISSN (print) - 2520-6761

2. 33,000 girls become child brides every day. Globally, 12 million girls each year get married before the age of 18 - roughly 33,000 every day, or one every two seconds. There are some 650 million women alive today who child brides were. The reasons behind it vary between communities, but it's often because girls are not valued as highly as boys and marrying them off at a young age transfers the 'economic burden' to another family.

3. Women in rural parts of Africa spend 40 billion hours a year collecting water.

4. It will take 108 years to close the gender gap.

5. Only 6 countries give women equal legal work rights as men. The World Bank's recent "Women, Business and the Law" report measured gender discrimination in 187 countries. It found that only Belgium, Denmark, France, Latvia, Luxembourg and Sweden scored full marks on eight indicators - from receiving a pension to freedom of movement - influencing economic decisions women make during their careers. A typical economy only gives women three-quarters the rights of men in the measured areas.

6. $22 \%$ of Artificial Intelligence professionals are women - and it could be down to lack of confidence. A 2015 PISA report found even high-achieving girls underachieved when they were asked to 'think like scientists'. Girls were less confident at solving science and maths problems and reported higher levels of anxiety towards maths. In a study of students at Cornell University in 2003, psychologists found that women rated their scientific abilities lower than men, even though they performed roughly the same in a quiz.

7. For every female film character, there are 2.24 men. The Geena Davis Institute analyzed 120 theatrical releases between 2010 and 2013 in 10 countries - and found that of the 5,799 speaking or named characters, less than a third (30.9\%) were female and more than a third (69.1\%) were male (Whiting K., 2019, an article from www.weforum.org, cited in the references).

The Global Gender Gap Index was introduced by the World Economic Forum in 2006 for capturing the magnitude of gender-based disparities and tracking their progress over time. This year the report benchmarks 149 countries on their progress towards gender parity on a scale from 0 (disparity) to 1 (parity) across four thematic dimensions - the sub-indexes "Economic Participation and Opportunity", "Educational Attainment", "Health and Survival", and "Political Empowerment" (The Global Gender Gap Report, 2018, http://www3.weforum.org/docs/WEF_GGGR_2018.pdf). It's going to take 108 years to close the Global Gender Gap, which is now 68\% (Western Europe-76\%, North America-73\%, Eastern Europe and Central Asia$71 \%$, Latin America and the Caribbean-71\%, East Asia and the Pacific-68\%, Sub-Saharan Africa-66\%, South Asia-66\%, Middle East and North Africa-60\%).

Iceland is in the index's top, then come Norway, Sweden, Finland. Iraq, Pakistan, and Yemen are at the end of the index (The Global Gender Gap Report, 2018).

Table 1. Global Gender Gap Index of Some Countries, 2018

\begin{tabular}{|c|c|c|c|c|c|c|c|c|c|c|}
\hline \multirow[b]{2}{*}{ Country } & \multicolumn{2}{|c|}{ Global Index } & \multicolumn{2}{|c|}{$\begin{array}{c}\text { Economic } \\
\text { Participation and } \\
\text { Opportunity }\end{array}$} & \multicolumn{2}{|c|}{$\begin{array}{l}\text { Educational } \\
\text { Attainment }\end{array}$} & \multicolumn{2}{|c|}{$\begin{array}{l}\text { Health and } \\
\text { Survival }\end{array}$} & \multicolumn{2}{|c|}{$\begin{array}{c}\text { Political } \\
\text { Empowerment }\end{array}$} \\
\hline & Rank & $\begin{array}{c}\text { Score } \\
(0-1)\end{array}$ & Rank & $\begin{array}{c}\text { Score } \\
(0-1)\end{array}$ & Rank & $\begin{array}{c}\text { Score } \\
(0-1)\end{array}$ & Rank & $\begin{array}{l}\text { Score } \\
(0-1)\end{array}$ & Rank & $\begin{array}{c}\text { Score } \\
(0-1)\end{array}$ \\
\hline Iceland & 1 & 0.858 & 16 & 0.793 & 39 & 0.999 & 121 & 0.968 & 1 & 0.674 \\
\hline Norway & 2 & 0.835 & 11 & 0.806 & 41 & 0.999 & 95 & 0.972 & 3 & 0.563 \\
\hline Sweden & 3 & 0.822 & 9 & 0.808 & 52 & 0.998 & 115 & 0.969 & 7 & 0.512 \\
\hline Finland & 4 & 0.821 & 17 & 0.786 & 1 & 1.000 & 60 & 0.977 & 6 & 0.519 \\
\hline Nicaragua & 5 & 0.809 & 69 & 0.679 & 36 & 1.000 & 1 & 0.980 & 2 & 0.576 \\
\hline Rwanda & 6 & 0.804 & 30 & 0.743 & 109 & 0.961 & 90 & 0.973 & 4 & 0.539 \\
\hline New Zealand & 7 & 0.801 & 23 & 0.761 & 1 & 1.000 & 107 & 0.970 & 9 & 0.472 \\
\hline Philippines & 8 & 0.799 & 14 & 0.801 & 1 & 1.000 & 42 & 0.979 & 13 & 0.416 \\
\hline Ireland & 9 & 0.796 & 43 & 0.725 & 57 & 0.996 & 111 & 0.970 & 8 & 0.493 \\
\hline Namibia & 10 & 0.789 & 12 & 0.804 & 42 & 0.999 & 1 & 0.980 & 20 & 0.375 \\
\hline Azerbaijan & 97 & 0.680 & 47 & 0.716 & 33 & 1.000 & 146 & 0.941 & 137 & 0.063 \\
\hline Armenia & 98 & 0.678 & 73 & 0.675 & 35 & 1.000 & 148 & 0.939 & 115 & 0.099 \\
\hline Georgia & 99 & 0.677 & 85 & 0.654 & 60 & 0.996 & 123 & 0.967 & 119 & 0.093 \\
\hline Turkey & 130 & 0.628 & 131 & 0.466 & 106 & 0.968 & 67 & 0.976 & 113 & 0.101 \\
\hline Iran, Islamic Rep. & 142 & 0.589 & 143 & 0.376 & 103 & 0.969 & 127 & 0.966 & 141 & 0.046 \\
\hline Iraq & 147 & 0.551 & 149 & 0.264 & 136 & 0.829 & 76 & 0.975 & 90 & 0.135 \\
\hline Pakistan & 148 & 0.550 & 146 & 0.318 & 139 & 0.810 & 145 & 0.946 & 97 & 0.127 \\
\hline Yemen & 149 & 0.499 & 147 & 0.299 & 146 & 0.718 & 126 & 0.966 & 149 & 0.014 \\
\hline
\end{tabular}


Azerbaijan (97) and Armenia (98) see improvements in closing their education gender gap, despite remaining among the worst-performing countries globally on the Health and Survival sub-index. In particular, they record some of the lowest female-to-male sex ratios at birth in the world, just above China's. They are followed closely by Georgia (99) - which also improves on Educational Attainment, yet reverses previous gains in wage equality and women's share of senior leadership positions (The Global Gender Gap Report, 2018).

Table 2. Global Gender Gap Index of Armenia, 2018

\begin{tabular}{|l|c|c|c|c|c|c|}
\hline & Rank & Score & Average & Female & Male & f/m \\
\hline Economic participation and opportunity & 73 & 0.675 & 0.586 & - & - & - \\
\hline Labor force participation & 84 & 0.762 & 0.669 & 5707 & 75.7 & 0.76 \\
\hline Wage equality for similar work (survey) & 38 & 0.709 & 0.645 & - & - & 0.71 \\
\hline Estimated earned income (PPP, US\$) & 99 & 0.545 & 0.510 & 6.926 & 12.714 & 0.54 \\
\hline Legislators, senior officials and managers & 86 & 0.419 & 0.329 & 29.5 & 70.5 & 0.42 \\
\hline Professional and technical workers & 1 & 1.000 & 0.753 & 61.6 & 38.4 & 1.60 \\
\hline Educational attainment & 35 & 1.000 & 0.949 & - & - & - \\
\hline Literacy rate & 49 & 0.999 & 0.882 & 99.7 & 99.8 & 1.00 \\
\hline Enrolment in primary education & 69 & 0.999 & 0.978 & 92.0 & 92.1 & 1.00 \\
\hline Enrolment in secondary education & 1 & 1.000 & 0.967 & 88.1 & 87.5 & 1.01 \\
\hline Enrolment in tertiary education & 1 & 1.000 & 0.939 & 58.7 & 46.1 & 1.27 \\
\hline Health and survival & 148 & 0.939 & 0.955 & - & - & - \\
\hline Sex ratio at birth & 148 & 0.886 & 0.921 & - & - & 0.89 \\
\hline Healthy life expectancy & 1 & 1.060 & 1.034 & 68.7 & 63.6 & 1.08 \\
\hline Political empowerment & 115 & 0.099 & 0.223 & - & - & - \\
\hline Women in parliament & 96 & 0.221 & 0.284 & 18.1 & 81.9 & 0.22 \\
\hline Women in ministerial positions & 109 & 0.125 & 0.208 & 11.1 & 88.9 & 0.12 \\
\hline Years with female head of state (last 50) & 71 & 0.000 & 0.189 & 0.0 & 50.0 & 0.00 \\
\hline Solr: & & & & & \\
\hline
\end{tabular}

Source: The Global Gender Gap Report 2018, World Economic Forum, Geneva, pp. 3-73, URL: http://www3.weforum.org/docs/WEF_GGGR_2018.pdf

So, we have problems with health and survival index, political empowerment index, Labor force participation, Estimated earned income (PPP, US\$), Legislators, senior officials and managers sub-indexes.

Now we will discuss the statistical data available in Armenia about the above-mentioned issues.

According to Table 3, in each and every area of occupation women are paid less than men, and there is no other sector that women are paid more. Analyzing the data, we can conclude that average differences between the earnings of men and women are nearly $32.5 \%$ and the biggest differences are in the sector of finance and insurance $-39.8 \%$. As you can see, the highest payment rent is in the areas where the difference between men' and women' salaries is the biggest.

The situation is more or less better in the sectors of electricity, gas, steam and air conditioning supply, the difference is not much, only $3.6 \%$, on the second place comes sector of water supply with the difference of 9.9\%. In other areas, the difference becomes even drier (Women and Men in Armenia 2018 Statistic Booklet, The Statistical Committee of the Republic of Armenia 2018: 87).

Table 3. Average Monthly Nominal Wages/Salaries by Types of Economic Activity, 2017

\begin{tabular}{|c|c|c|c|}
\hline & Women (AMD) & Men (AMD) & W/M \% \\
\hline Total & 143016 & 211720 & 67.5 \\
\hline Agriculture, forestry and fishing & 101838 & 128614 & 79.2 \\
\hline Mining and quarrying & 295257 & 429210 & 68.8 \\
\hline Manufacturing & 124461 & 183155 & 68.0 \\
\hline Electricity, gas, steam and air conditioning supply & 261504 & 271149 & 96.4 \\
\hline Water supply; sewerage, waste management, and remediation activities & 152157 & 168823 & 90.1 \\
\hline Construction & 154617 & 176771 & 87.5 \\
\hline Wholesale and retail trade; repair of motor vehicles and motorcycles & 114891 & 147981 & 77.6 \\
\hline Transportation and storage & 132829 & 162049 & 82.0 \\
\hline Accommodation and food service activities & 104126 & 124991 & 83.3 \\
\hline Information and communication & 305397 & 441329 & 69.2 \\
\hline Financial and insurance activities & 321343 & 533885 & 60.2 \\
\hline Real estate activities & 119209 & 155490 & 82.5 \\
\hline Professional, scientific and technical activities & 158591 & 213964 & 74.1 \\
\hline Administrative and support service activities & 123982 & 158727 & 78.1 \\
\hline Public, administrative and defense; compulsory social security & 200412 & 233065 & 86.0 \\
\hline Education & 114253 & 142526 & 80.2 \\
\hline Human health and social work activities & 131408 & 190164 & 69.1 \\
\hline Arts, entertainment and recreation & 107301 & 119852 & 89.5 \\
\hline Other service activities & 112525 & 132315 & 85.0 \\
\hline
\end{tabular}

Source: Women and Men in Armenia 2018 Statistic Booklet, The Statistical Committee of the Republic of Armenia 2018: 87 
ISSN (online) - 2520-6311; ISSN (print) - 2520-6761

Now, let us look at the salaries of men and women by institutional sectors. As we can notice, women are more exploited in the public sector rather than in the non-public sector. In the public sector, men are paid $32.9 \%$ more than women are. In the non-public sector, the difference is $28.6 \%$. And all this disparity is displayed in everyday life, whereas the state has an obligation to pursue a policy that protects the rights of women and gender equality. Additionally, we have to point out that even the main law, that is the Constitution of Armenia, in its article 86 states that one of the main objectives of state policy in the economic, social and cultural spheres shall be promoting actual equality between women and men. However, equal payment for the equal job is still an issue and the payment gap between men and women is still an everyday occurrence. Moreover, this disparity is more obvious in the public sector.

Table 4. Average Monthly Nominal Wages/Salaries by Institutional Sectors of Economy, 2017

\begin{tabular}{|l|c|c|c|}
\hline & $\begin{array}{c}\text { Women } \\
\text { (AMD) }\end{array}$ & $\begin{array}{c}\text { Men } \\
\text { (AMD) }\end{array}$ & $\begin{array}{c}\text { W/M } \\
\mathbf{\%}\end{array}$ \\
\hline Total & $\mathbf{1 4 3 0 1 6}$ & $\mathbf{2 1 1 ~ 7 2 0}$ & $\mathbf{6 7 . 5}$ \\
\hline Public & 131885 & 196595 & 67.1 \\
\hline Non-public & 157695 & 220937 & 71.4 \\
\hline
\end{tabular}

Source: Women and Men in Armenia 2018 Statistic Booklet, The Statistical Committee of the Republic of Armenia 2018: 88

The difference of average nominal wages (earnings) of women and men decreased by 8.3 percentage points over the last ten years. In 2017, the women's earnings amounted to $67.5 \%$ of men's earnings, so the gender pay gap is amounted $32.5 \%$. Even there is the progress but still the pay gap amount is too enormous and numbers are not encouraging.

In Armenia the unemployment rate is high, and even though women are paid less than man doing the same job, long-term unemployment rate is especially high among the former, reaching up to $57 \%$ of unemployed female population (Women and Men in Armenia 2018 Statistic Booklet, The Statistical Community of the Republic of Armenia 2018: 90).

There are various laws that protect women's rights in gender equality. The National Assembly of the Republic of Armenia has adopted a law in 2013 about "The Insurance of Equal Rights and Equal Opportunities for Women and Men" (The low of the Republic of Armenia "The Insurance of Equal Rights and Equal Opportunities for Women and Men" 2013). In another document "The Electoral Code of the Republic of Armenia", there is a provision article 83 that states that the number of representatives in the National Assembly of the Republic of Armenia each gender should not exceed 70 percent (The low of the Republic of Armenia "The Electoral Code of the Republic of Armenia", 2016), so in 2017 from 105 members only 19 were females. In 2018 from 132 deputies only 32 elected are women.

However, in the executive branch, which is not regulated by any legislative norms there was only one female minister, and there were only 2 female deputy ministers from 57 deputy ministers.

Table 5. Ministries and Deputy Ministers, 2017

\begin{tabular}{|l|c|c|c|c|}
\hline & $\begin{array}{c}\text { Women } \\
\text { (Person) }\end{array}$ & $\begin{array}{c}\text { Men } \\
\text { (Person) }\end{array}$ & $\begin{array}{c}\text { Women } \\
(\boldsymbol{\%})\end{array}$ & $\begin{array}{c}\text { Men } \\
(\boldsymbol{\%})\end{array}$ \\
\hline Total & $\mathbf{3}$ & $\mathbf{7 2}$ & $\mathbf{4}$ & $\mathbf{9 6}$ \\
\hline Ministers & 1 & 17 & 5.6 & 94.4 \\
\hline Deputy Ministers & 2 & 55 & 3.5 & 96.5 \\
\hline
\end{tabular}

Source: Women and Men in Armenia 2018 Statistic Booklet, The Statistical Committee of the Republic of Armenia 2018: 96-100

It should be noted that there was no other female among the heads of 10 provinces and among the mayors of 49 cities in 2017, however among 502 heads of local communities 8 were female. So, to sum up, we can affirm that women have little involvement in state and local governance.

Table 6. Marz Governor (Marzpet) Head and Council Members of Community, 2017

\begin{tabular}{|l|c|c|c|c|c|}
\hline & Total & $\begin{array}{c}\text { Women } \\
\text { (Person) }\end{array}$ & $\begin{array}{c}\text { Men } \\
\text { (Person) }\end{array}$ & $\begin{array}{c}\text { Women } \\
(\boldsymbol{\%})\end{array}$ & $\begin{array}{c}\text { Men } \\
(\boldsymbol{\%})\end{array}$ \\
\hline Marzpet (Head of the province) & 10 & - & 10 & - & 100 \\
\hline Head of community & 502 & 8 & 494 & 1.6 & 98.4 \\
\hline Of which; Yerevan city & 1 & - & 1 & - & 100 \\
\hline Council members of community & 3830 & 401 & 3429 & 10.5 & 89.5 \\
\hline Of which; Yerevan city & 65 & 20 & 45 & 30.8 & 69.2 \\
\hline
\end{tabular}

Source: Women and Men in Armenia 2018 Statistic Booklet, The Statistical Committee of the Republic of Armenia 2018: 96-100 
According to Figure 1, there are many women among the middle and low-skilled civil service employment. Among junior posts, $72 \%$ are female, among leading posts only 59\%, and so higher we ascend - less women there are in power positions, among chief posts $48 \%$, and among highest posts only $15 \%$.

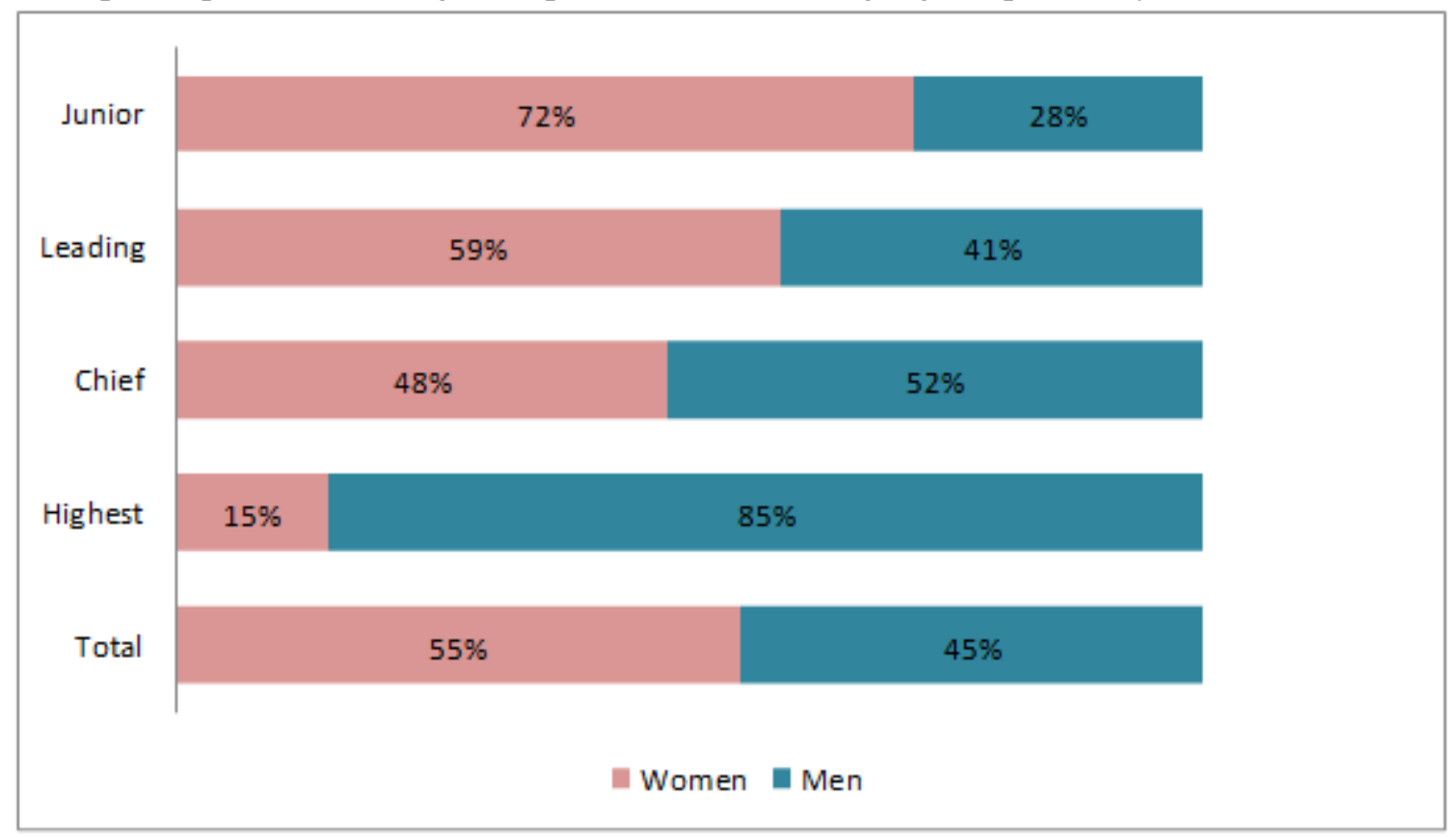

Figure 1. Posts of the Civil Service of RA, 2017

Source: Women and Men in Armenia 2018 Statistic Booklet, The Statistical Committee of the Republic of Armenia 2018: 103 Contrary to this, it should be mentioned that women are more educated.

BA programs have been offered in 61 state and non-state Armenian institutions with their 12 branches during 2017/2018 academic year. In these institutions, during 2017/2018 academic year, 15538 people (women $49.4 \%$ ) were admitted, during the same period totally 17787 people graduated and women among them were $61.3 \%$. The total enrollment rate of students in the universities is $56.4 \%$ (women $-61.8 \%$, men $-51.5 \%$ ). It is interesting that there are many men among those who have adopted a free educational system, $60 \%$ are male students in bachelor studying system. But at the end of their education, the situation changes and among all the graduates 62,4\% are female (Higher Professional Education, Social status of the Republic of Armenia 2017).

In Armenia Master programs have been offered in 20 state higher educational institutions with their 9 branches and 3 scientific organizations during 2017/2018 academic year. This institutions admitted 5881 people (women $-70.6 \%$ ), and graduated 4376 (women $-58.3 \%$ ). In the above mentioned institutions female professorial staff makes only 52\% (Higher Professional Education, Social status of the Republic of Armenia 2017). Among students who receive post-graduate education, women again are more inclined to apply than men. During 2017, 265 people were accepted as postgraduate students and 57.7\% were women. Among the graduates again women are more than men $-51.7 \%$ (Postgraduate education, Social status of the Republic of Armenia 2017). As you can see, women study better, make more effort, receive higher qualified education, study more languages, but at the same time something goes wrong and they don't get to have higher positions in their job and don't get the same payment as men.

It also should be noticed that women who have a higher educational level are employed more than women who have elementary, basic or secondary education. Among those women who have tertiary, post graduated and secondary specialized and vocational education employed women in 2016 were 55\%, in 2017 were 57.9\%, men accordingly were $49.7 \%$ and $46.9 \%$.

Table 7. Employed Persons by Educational Attainment 2016/2017

\begin{tabular}{|l|c|c|c|c|c|c|}
\hline & \multicolumn{2}{|c|}{ Total } & \multicolumn{2}{c|}{ Men } & \multicolumn{2}{c|}{ Women } \\
\hline & $\mathbf{2 0 1 6}$ & $\mathbf{2 0 1 7}$ & $\mathbf{2 0 1 6}$ & $\mathbf{2 0 1 7}$ & $\mathbf{2 0 1 6}$ & $\mathbf{2 0 1 7}$ \\
\hline Total & $\mathbf{1 0 0}$ & $\mathbf{1 0 0}$ & $\mathbf{1 0 0}$ & $\mathbf{1 0 0}$ & $\mathbf{1 0 0}$ & $\mathbf{1 0 0}$ \\
\hline Tertiary, postgraduate & 29.1 & 29.6 & 28.1 & 27.6 & 30.3 & 31.8 \\
\hline Secondary specialized, vocational & 23.1 & 22.5 & 21.6 & 19.3 & 24.7 & 26.1 \\
\hline General secondary & 42.2 & 43.6 & 43.3 & 47.9 & 41.0 & 38.8 \\
\hline General basic, primary and lower & 5.6 & 4.2 & 7.0 & 5.1 & 4.0 & 3.3 \\
\hline
\end{tabular}

Source: Employment 2016-2017, The Statistical Committee of the Republic of Armenia 2018: 79 
Table 8. Employed Persons by Status in Employment 2016/2017

\begin{tabular}{|l|c|c|c|c|c|c|}
\hline & \multicolumn{2}{|c|}{ Total } & \multicolumn{2}{c|}{ Men } & \multicolumn{2}{c|}{ Women } \\
\hline & $\mathbf{2 0 1 6}$ & $\mathbf{2 0 1 7}$ & $\mathbf{2 0 1 6}$ & $\mathbf{2 0 1 7}$ & $\mathbf{2 0 1 6}$ & $\mathbf{2 0 1 7}$ \\
\hline Total & $\mathbf{1 0 0}$ & $\mathbf{1 0 0}$ & $\mathbf{1 0 0}$ & $\mathbf{1 0 0}$ & $\mathbf{1 0 0}$ & $\mathbf{1 0 0}$ \\
\hline Employee & 58.0 & 59.6 & 57.1 & 58.6 & 59.0 & 60.8 \\
\hline Employer & 1.0 & 1.2 & 1.6 & 1.9 & 0.4 & 0.5 \\
\hline Own-account worker & 34.9 & 36.8 & 37.7 & 38.2 & 31.9 & 35.2 \\
\hline Contributing family workers & 6.0 & 2.4 & 3.6 & 1.4 & 8.7 & 3.4 \\
\hline
\end{tabular}

Source: Employment 2016-2017, The Statistical Committee of the Republic of Armenia 2018: 85

Among employed people in 2017 employer women were only $0.5 \%$, nearly four times less than men, but women do household, daily chores in total $3.4 \%$, by 58.8 percentage points more than men. Thus, women are more engaged in household chores, they face all their daily needs, they do not have time for self-actualization, they do not have time for their career, promotion, and as a result, they lose a huge potential.

\section{Methodology}

The aim of the research is exploring gender inequality issues in Armenia. For that purpose statistical data were used by the Statistical Committee of the RA, also Gender Gap report was analyzed.

The main findings were based on a sociological survey among the population, the results of which were analyzed by statistical methods. After formulating a database, the key results were obtained by using Crosstabulations with Pearson Chi-square coefficient testing (setting significance level $\alpha=0.05$ ). The value of the Chi-Square statistic provides a test of whether or not there is a statistical relationship between the variables in the cross-classification table.

\section{Data Analysis and Findings}

For exploring the current situation in workplaces connected with gender equality issues and revealing the opinions and experiences of people, we have conducted a survey among 200 people in Armenia, during March 2019.

The results of the survey are as follows: $89 \%$ of the participants were female, $48 \%$ were up to 25 years old and $43 \%-26-35$ years old, $74 \%$ had higher education, working in different spheres of the economy.

Table 9. Main characteristics of survey participants

\begin{tabular}{|c|c|c|}
\hline & Quantity & Share in the total, \% \\
\hline \multicolumn{3}{|l|}{ Gender } \\
\hline Female & 178 & 89 \\
\hline Male & 22 & 11 \\
\hline \multicolumn{3}{|l|}{ Age } \\
\hline up to 25 years old & 96 & 48 \\
\hline 26-35 years old & 86 & 43 \\
\hline $36-50$ years old & 16 & 8 \\
\hline 51 and older & 2 & 1 \\
\hline \multicolumn{3}{|l|}{ Education } \\
\hline Higher & 148 & 74 \\
\hline Post-graduate & 25 & 12,5 \\
\hline Vocational & 19 & 9,5 \\
\hline Secondary & 8 & 4 \\
\hline \multicolumn{3}{|l|}{ Occupation } \\
\hline Student & 10 & 5 \\
\hline Financial sector & 20 & 10 \\
\hline Health sphere & 11 & 5,5 \\
\hline Trade & 15 & 7,5 \\
\hline Tourism & 11 & 5,5 \\
\hline Culture & 7 & 3,5 \\
\hline Education sphere & 39 & 19,5 \\
\hline Journalism and media & 3 & 1,5 \\
\hline Public sphere & 7 & 3,5 \\
\hline IT & 7 & 3,5 \\
\hline Other & 70 & 35 \\
\hline
\end{tabular}

Source: Own adjustment based on the analysis of the survey 
$56 \%$ of the participants believed in gender equality, $72 \%$ was thinking that gender inequality is an issue in Armenia, however, only $25.5 \%$ mentioned that there is gender inequality in the place he/she studies or works. $46 \%$ has ever faced gender inequality himself/herself.

Table 10. Main perceptions of gender inequality of survey participants

\begin{tabular}{|l|c|c|}
\hline \multicolumn{2}{|c|}{ Quantity } & Share in the total, \% \\
\hline Do you believe in gender equality? & 112 & 56 \\
\hline Yes & 52 & 15,5 \\
\hline No & 31 & 2,5 \\
\hline It is difficult to answer & 5 & 72 \\
\hline Other & 144 & 19,5 \\
\hline Do you think that gender inequality is an issue in Armenia? & 39 & 6,5 \\
\hline Yes & 13 & 2 \\
\hline No & 4 & 25,5 \\
\hline I do not know & & 64,5 \\
\hline in some cases & 51 & 8,5 \\
\hline Is there gender inequality in the place you study or work? & 129 & 1,5 \\
\hline Yes & 17 & \\
\hline No & 3 & 46 \\
\hline I do not know & & \\
\hline Other & 92 & 9 \\
\hline Yes & 90 & \\
\hline No & 18 & \\
\hline It is difficult to answer & \\
\hline
\end{tabular}

Source: Own adjustment based on the analysis of the survey

The most frequent issues of gender inequality that the participants had ever faced were: low opportunity of career promotion (28.5\%), dress code (15.5\%), bad attitude (12.5\%), some work restrictions $(11.5 \%)$

Table 11. What gender inequality cases have you faced in your University or workplace?

\begin{tabular}{|c|c|c|}
\hline & Quantity & Share in the total, \% \\
\hline low opportunity of career promotion & 57 & 28.5 \\
\hline dress code & 31 & 15.5 \\
\hline I have not ever faced any case of gender inequality & 26 & 13 \\
\hline bad attitude & 25 & 12.5 \\
\hline some work restrictions & 23 & 11.5 \\
\hline low wages & 22 & 11 \\
\hline have not mentioned anything & 9 & 4.5 \\
\hline sexual harassment & 4 & 2 \\
\hline other (for example, the fact of being married) & 3 & 1.5 \\
\hline
\end{tabular}

Source: Own adjustment based on the analysis of the survey

The participants were subject to gender discrimination by the manager, family member, colleague, lecturer.

Table 12. By whom were you subject to gender discrimination?

\begin{tabular}{|l|c|c|}
\hline & Quantity & Share in the total, \% \\
\hline no one & 108 & 54 \\
\hline manager/director & 27 & 13.5 \\
\hline family member & 27 & 13.5 \\
\hline Colleague & 14 & 7 \\
\hline Lecturer & 14 & 7 \\
\hline Other & 8 & 4 \\
\hline Customer & 2 & 1 \\
\hline
\end{tabular}

Source: Own adjustment based on the analysis of the survey

$50 \%$ of the participants thought that the educational system changes the attitude towards gender discrimination, and $27.5 \%$ thought that it changes very slowly.

Only $27 \%$ has mentioned that their gender has disrupted their professional promotion.

$73 \%$ thought that it is wrong that women are less paid than men for the same work. 
Table 13. Some issues of gender inequality by participants

\begin{tabular}{|c|c|c|}
\hline & Quantity & Share in the total, \% \\
\hline \multicolumn{3}{|c|}{ Do you think that the educational system changes the attitude towards gender discrimination? } \\
\hline Yes & 100 & 50 \\
\hline it is difficult to answer & 15 & 7.5 \\
\hline No & 24 & 12 \\
\hline changes, but very slowly & 55 & 27.5 \\
\hline Other & 6 & 3 \\
\hline \multicolumn{3}{|c|}{ Has your gender ever disrupted your professional promotion? } \\
\hline Yes & 54 & 27 \\
\hline it is difficult to answer & 20 & 10 \\
\hline No & 126 & 63 \\
\hline \multicolumn{3}{|c|}{ Do you know that only $0.5 \%$ of employers in the Armenian labor market are women? } \\
\hline Yes & 30 & 15 \\
\hline No & 56 & 28 \\
\hline I thought even more & 107 & 53.5 \\
\hline I thought even less & 7 & 3.5 \\
\hline \multicolumn{3}{|c|}{ In your opinion, is it right, that women are less paid than men for the same work? } \\
\hline yes, it is right & 10 & 5 \\
\hline no, it is wrong & 146 & 73 \\
\hline it is right partly, in some cases & 39 & 19.5 \\
\hline Other & 5 & 2.5 \\
\hline
\end{tabular}

Source: Own adjustment based on the analysis of the survey

The main steps mentioned by the participants for regulating the issue of gender inequality were: raising the level of awareness of the people about the subject, making gender equality a component of the educational system, improving the public policy, taking certain actions against employers, etc.

Table 14. How do you think this issue can be regulated?

(the participants could mention more than one option)

\begin{tabular}{|c|c|c|}
\hline & Quantity & Share in the total, \% \\
\hline to improve public policy & 63 & 31.5 \\
\hline certain actions against employers & 39 & 19.5 \\
\hline the result of lobbying by deputies & 13 & 6.5 \\
\hline more coordinated efforts by non-governmental organizations & 43 & 21.5 \\
\hline to make gender equality a component of the educational system & 97 & 48.5 \\
\hline raise the level of awareness of the people about the subject & 130 & 65 \\
\hline Other & 6 & 3 \\
\hline
\end{tabular}

Source: Own adjustment based on the analysis of the survey

It was also interesting to reveal if there is any relationship between some factors. That is why we have done Crosstabulations with Pearson Chi-Square coefficient testing using SPSS software. The significance level is more than 0.005 , so we may consider that the relationship exists between the factors.

Table 15. Chi-Square Testing

\begin{tabular}{|l|c|c|}
\hline & \multicolumn{2}{|c|}{ Pearson Chi-Square } \\
\cline { 2 - 3 } & Value & Approx. Sig. \\
\hline Gender * Have you ever faced gender inequality yourself? & 2.082 & .556 \\
\hline Do you believe in gender equality? * Have you ever faced gender inequality yourself? & 12.859 & .913 \\
\hline $\begin{array}{l}\text { Do you believe in gender equality? * Has your gender ever disrupted your professional } \\
\text { promotion? }\end{array}$ & 22.858 & .352 \\
\hline $\begin{array}{l}\text { Have you ever faced gender inequality yourself? * Do you think that gender inequality is } \\
\text { an issue in Armenia? }\end{array}$ & 42.322 & .012 \\
\hline Age * Have you ever faced gender inequality yourself? & 6.981 & .639 \\
\hline Education level * Have you ever faced gender inequality yourself? & 7.436 & .592 \\
\hline
\end{tabular}

Source: The analysis in the table was done using SPSS software

Pearson Chi-Square coefficient testing shows that there is a significant relationship between the gender of participants and the fact that they had ever faced gender inequality. In particular, from 178 females 78 faced gender inequality. From 112 participants who believe in gender equality, 48 faced inequality. From 92 participants who had ever faced gender inequality 76 thought that gender inequality is an issue in Armenia. From 92 participants who had ever faced gender inequality, 43 were 26-35 years old and 37 were up to 25 years old. From 148 participants who had higher education, 70 faced gender inequality and 66 not. 
Thus, our analysis shows that there is a real problem connected with gender discrimination in workplaces. There may be even people, who do not want to tell if they have ever faced that problem. That is why the awareness of the people must be raised, and they must not be afraid to tell about their bad experiences.

\section{Conclusion}

As a result of our analyses, here we can summarize the main issues connected with gender discrimination in the Armenian labor market and mention the main steps for the regulation of the problem.

Females are more involved in educational institutions than males; however, the situation changes in the labor market. The statistics states that there are more male workers than females and their salary is much higher. Besides, our survey reveals, that female workers frequently have some problems in workplaces due to their gender. These problems are various: low opportunities for career promotion, dress code, bad attitude, work restrictions, etc.

In order to solve gender inequality in the workplaces, the most efficient thing to do will be the installment of written policies of gender equality promotions. These policies should ensure that men and women have equal rights and they should be paid equally for the same work. Policies should ensure equality in all levels of HR development: recruitment, hiring, training, career promotion, payment, and rewards. These policies should make it possible to balance personal and professional lives of employees. Moreover, the most important thing is that these policies should include the prohibition of any kind of harassment, especially sexual harassment. And in the end, the policies should have a procedure for reporting gender discrimination cases without consequences or fear. These types of policies are a good step towards solving many problems in workplaces. But the state should adopt a law, which will force organizations to set up such policies, as many organizations will not follow the necessary steps if it is not mandatory.

Thus, as a summary, we may resume the main steps, which are necessary for improving gender inequality issues in Armenia. First of all the awareness of people about the subject should be increased. Gender equality issues must be a component of the educational system, children must learn from school that all people have equal rights. Another issue is the mentality of the population. Many people think that after education girls should marry and have children, as for work, it is for men. That is why employers tend to have male workers. Furthermore, females are not promoted to higher positions and are paid less. And here the educated women had to stay at home and lose their qualifications. Besides, there is a need to improve public policy, take some actions for employers. Likewise, the role of more coordinated efforts by non-governmental organizations is also important, as many women turn to NGO's when they have problems regarding gender discrimination. Men and women have equal rights to study and work, but gender discrimination is a real problem to be solved by the systematic effort of people, communities, NGO's, public and private organizations, states.

So we came to the following conclusions:

1. The first problem with gender inequality that must be addressed is changing the mentality of the population. To solve this problem gender equality must be a component of the educational system, in order to increase population awareness and to change their mentality,

2. There is a necessity for a regulation of the gender discrimination problem through legislative interventions. We can conclude from the analysis of the above mentioned data that the state is the most discriminatory body in Armenia, and until gender equality is a problem in public sector, we will not be able to regulate it in the private one.

3. According to the above mentioned analysis, there are only 0.5 percent women employees, so we must do some actions to stimulate female businesswoman so that they will start making changes on their own, and not wait for any benefactions from the government or someone else.

4. It is necessary to make TV, radio and online programs about gender equality to increase the legal consciousness of the people.

5. According to Global Gender Gap Index, Iceland is the best place to be a woman, it has closed $86 \%$ of its gap, the most remarkable thing is that both mother and father are given at least 3 months paid parental leave. In Armenia, such a change will be a good opportunity and will give women a chance not to stop working after having a baby. 


\section{References}

1. Auspurg, Katrin, Hinz, Thomas, Sauer, Carsten (2017). Why Should Women Get Less? Evidence on the Gender Pay Gap from Multifactorial Survey Experiments. American Sociological Review 2017, 82(1), 179210. DOI: $10.1177 / 0003122416683393$.

2. Blau, F. D., and DeVaro, J. (2007). New evidence on gender differences in promotion rates: an empirical analysis of a sample of new hires. Ind. Relat. 46, 511-550. doi: 10.1111/j.1468-232X.2007.00479.x.

3. Cohen, P. N., Huffman, M. L. (2007). Working for the Woman? Female Managers and the Gender Wage Gap. American Sociological Review, 72, 681-704. DOI: 10.1177/000312240707200502.

4. Correll, S., Stephen, B., and In Paik (2007). Getting a Job: Is There a Motherhood Penalty? American Journal of Sociology, 112, 1297-1339.

5. Cox, T. H., and Harquail, C. V. (1991). Career paths and career success in the early career stages of male and female MBAs. J. Vocat. Behav. 39, 54-75. doi:10.1016/0001-8791(91)90004-6.

6. Dodd-McCue, Diane, and Gail, B. Wright (1996). Men, Women, and Attitudinal Commitment: The Effects of Workplace Experiences and Socialization. Human Relations, 49, 1065-1091.

7. Eagly, A. H., and Carli, L. L. (2007). Through the Labyrinth: The Truth about How Women become Leaders. Boston, MA: Harvard Business School Publishing.

8. Eagly, Alice H., Steven, J. Karau, and Mona, G. Makhijani (1995). Gender and the Effectiveness of Leaders: A Meta-Analysis. Psychological Bulletin, 117(1), 125-145.

9. Epstein, Cynthia Fuchs (2004). Border Crossings: The Constraints of Time Norms in Transgressions of Gender and Professional Roles. In Fighting For Time: Shifting Boundaries of Work and Social Life. Edited by Cynthia Fuchs Epstein and Arne L. Kalleberg. New York: Russell Sage Foundation, pp. 317-340.

10.Employment 2016-2017, The Statistical Committee of the Republic of Armenia (2018). URL: https://www.armstat.am/file/article/trud_18_4.1.pdf?fbclid=IwAR1K7i8wW6F4XmTYjV6v7vYu7UAXoNLXwNfHNeEgywX1IKXgHw6jycrUk8 (Accessed: 01.04.2019).

11.Fuegen, K., Biernat, M., Haines, E., and Deaux, K. (2004). Mothers and Fathers in the Workplace: How Gender and Parental Status Influence Judgments of Job-Related Competence. Journal of Social Issues, 60, 737-754.

12.Goldberg, P. (1968). Are women prejudiced against women? Transaction, 5, 316-322.

13.Hebl, M. R., King, E. B., Glick, P., Singletary, S. L., and Kazama, S. (2007). Hostile and benevolent reactions toward pregnant women: Complementary interpersonal punishments and rewards that maintain traditional roles. Journal of Applied Psychology, 92(6), Nov 2007, 1499-1511.

14.Heilman, M., and Okimoto, T. G. (2007). Why are women penalized for success at male tasks? The implied communality deficit. Journal of Applied Psychology, 92, 81-92. doi: 10.1037/0021-9010.92.1.81.

15.Heilman, M., and Okimoto, T. G. (2008). Motherhood: a potential source of bias in employment decisions. Journal of Applied Psychology, 93, 189-198. doi: 10.1037/0021-9010.93.1.189.

16.Higher Professional Education, Social status of the Republic of Armenia (2017). URL: https://www.armstat.am/file/article/soc_vich_2017_6.pdf (Accessed: 01.04.2019).

17.Hough, L. M., Oswald, F. L., and Ployhart, R. E. (2001). Determinants, detection, and amelioration of adverse impact in personnel selection procedures: issues, evidence, and lessons learned. Int. J. Sel. Assess, 9, 152-194. doi: 10.1111/1468-2389.00171.

18.King, E. B., Botsford, W., Hebl, M. R., Kazama, S., Dawson, J. F., and Perkins, A. (2012). Benevolent sexism at work: gender differences in the distribution of challenging developmental experiences. J. Manag, 38, 1835-1866. doi:10.1177/0149206310365902.

19.Lazear, E. P., and Rosen, S. (1990). Male-female wage differentials in job ladders. Journal of Labor Economics, 8, 106-122.

20.Lyness, K. S., and Heilman, M. E. (2006). When Fit Is Fundamental: Performance Evaluations and Promotions of Upper-Level Female and Male Managers. Journal of Applied Psychology, 91(4), 777-785.

21.Martell, R. F., Lane, D. M., and Emrich, C. (1996). Male-female differences: a computer simulation. Am. Psychol., 51, 157-158. doi: 10.1037/0003-066X.51.2.157.

22.Morgan, W. B., Walker, S. S., Hebl, M. R., and King, E. B. (2013). A field experiment: reducing interpersonal discrimination toward pregnant job applicants. Journal of Applied Psychology, 98, 799-809. doi: $10.1037 / \mathrm{a} 0034040$.

23.Paustian-Underdahl, Samantha C., Lisa Slattery Walker, and David J. Woehr (2014). Gender and Perceptions of Leadership Effectiveness: A Meta-Analysis of Contextual Moderators. Journal of Applied Psychology, 99(6), 1129-1145. 
24.Plickert, Gabriele, Sterling, Joyce (2017). Gender Still Matters: Effects of Workplace Discrimination on Employment Schedules of Young Professionals, Laws 2017, 6(4), 28; Available at: https://doi.org/10.3390/laws6040028.

25.Postgraduate education, Social status of the Republic of Armenia (2017). URL: https://www.armstat.am/file/article/soc_vich_2017_7.pdf (Accessed: 01.04.2019).

26.Roth, P. L., Purvis, K. L., and Bobko, P. (2012). A meta-analysis of gender group differences for measures of job performance in field studies. J. Manag, 38, 719-739. doi: 10.1177/0149206310374774.

27.Rudman, L. A., and Phelan, J. E. (2008). Backlash effects for disconfirming gender stereotypes in organizations. Res. Organ. Behav., 28, 61-79. doi:10.1016/j.riob.2008.04.003.

28.Rudman, L. A., Moss-Racusin, C. A., Phelan, J. E., and Nauts, S. (2012). Status incongruity and backlash effects: defending the gender hierarchy motivates prejudice against female leaders. J. Exp. Soc. Psychol., 48, 165-179. doi: 10.1016/j.jesp.2011.10.008.

29.Rosen, B., and Jerdee, T. H. (1974). Effects of applicant's sex and difficulty of job on evaluations of candidates for management positions. J. Appl. Psychol., 59, 511-512. doi: 10.1037/h0037323.

30.Stamarski, Cailin S., Hing, Leanne S. Son (2015). Gender inequalities in the workplace: the effects of organizational structures, processes, practices, and decision makers' sexism. Front. Psychol., 16 September 2015 | https://doi.org/10.3389/fpsyg.2015.01400.

31.Stroh, L. K., Brett, J. M., and Reilly, A. H. (1992). All the right stuff: a comparison of female and male managers' career progression. Journal of Applied Psychology, 77, 251-260. doi: 10.1037/00219010.77.3.251.

32.The Global Gender Gap Report (2018). World Economic Forum, Geneva, pp. 3-73, URL: http://www3.weforum.org/docs/WEF_GGGR_2018.pdf (Accessed: 01.04.2019).

33.The low of the Republic of Armenia "The Insurance of Equal Rights and Equal Opportunities for Women and Men" (2013).

34.The low of the Republic of Armenia "The Electoral Code of The Republic of Armenia" (2016).

35.Whiting, Kate (2019). 7 surprising and outrageous stats about gender inequality. URL: https://www.weforum.org/agenda/2019/03/surprising-stats-about-genderinequality?utm_source=Facebook $\% 20$ Videos\&utm_medium=Facebook\%20Videos\&utm_campaign=Fac ebook\%20Video\%20Blogs\&fbclid=IwAR3bfJzN6eKVtiVzSJF51AuKrwzsac_IhBrZ7nVWqNfRzP6yzva1_Aha_c (Accessed: 01.04.2019).

36. Women and Men in Armenia 2018 Statistic Booklet, The Statistical Committee of the Republic of Armenia (2018). URL: https://www.armstat.am/file/article/gender_2018.pdf (Accessed: 01.04.2019).

37.Yang, Tiantian, Aldrich, Howard E. (2014). Who's the Boss? Explaining Gender Inequality in Entrepreneurial Teams. American Sociological Review, 79(2), 303-327. DOI: 10.1177/0003122414524207. 